\title{
Onko tieteellä kansallista tehtävää?
}

Reetta Muhonen \& Hanna-Mari Puuska (toim.) (2014).

Tutkimuksen kansallinen tehtävä. Vastapaino: Tampere. $350 \mathrm{~s}$.

ISBN 978-951-768-416-3

TUTKIMUKSEN KANSALLINEN TEHTÄVÄ koostuu yhdestätoista artikkelista ja Jorma Sipilän kirjoittamista jälkisanoista. Tieteen kansallisesta tehtävästä puhutaan juuri nyt siksi, ettei sen hoitaminen ole enää itsestään selvää, kuten Sipilä toteaa. Myös käsitys kansallisesta tehtävästä on monitulkintaisempi kuin aiemmin.

Tieteellisten Seurain Valtuuskunnan julkaisufoorumi-hank- keen käynnistyttyä syntyi suoranainen liike suomen kielellä julkaisemisen puolesta: vaadittiin, että myös kotimaisten tieteellisten aikakauslehtien ja kustantajien on voitava yltää 2-tasolle. Muuten yliopistotutkijoiden julkaisutoiminta olisi suuntautunut niin kutsuttuihin kansainvälisiin journaaleihin. Ja kuten Otto Auranen ja Janne Pölönen Reetta Muhosen ja Hanna-Mari Puus- kan toimittamassa kirjassa toteavat, tutkijoiden vaatimus toteutui. Nyt julkaisufoorumissa on tasolle 2 luokiteltu 41 kotimaista lehteä ja julkaisusarjaa sekä neljä kustantajaa.

Tutkimuksen tehtäviä tarkastellaan kirjassa enimmäkseen yhteiskuntatieteellisen tutkimuksen näkökulmasta. Tutkimus osallistuu merkittävien globaalien ongelmien ratkaisemisen ohella 
kotimaiseen julkiseen keskusteluun nostamalla esiin kansallisia ongelmia. Näin se lisää ymmärrystä omasta yhteiskunnasta tarjoten myös aineksia poliittiseen päätöksentekoon. Kirjoittaminen suomen kielellä on osa kansallisen tehtävän toteuttamista. Kirjassa haetaan vastausta kysymyksiin, mitä on tutkimuksen yhteiskunnallinen vaikuttavuus, kenelle tutkimustuloksia julkaistaan, miten tutkimustuloksia hyödynnetään ja miten tieteen laatua ja tutkimuksen hyvyyttä mitataan.

\section{DIGITALISOITUMINEN ETENEE VÄÄJÄÄMÄTTÖMÄSTI}

Tiedekustantamisen intiaanit Teijo Makkonen (Vastapaino) ja Tuomas Seppä (ex-Gaudeamus) yhdessä Pekka Rantasen ja Jarno Valkosen kanssa jäsentävät tiedekustantamisen muuttuvaa maailmaa. Kenttä on kustannustoiminnan näkökulmasta laaja: siihen kuuluvat yhtälailla valtio ja markkinat kuin kansalaisyhteiskuntakin. Tiedekustantamisen talous on kaiken aikaa tiukentunut, ja kirjoittajat ennustavat suomalaisen tiedejulkaisemisen kaatuvan lähiaikoina kokonaan yliopistojen, Suomen Akatemian ja OKM:n varaan. Tiukkaa taloutta ei paikkaa edes open access -julkaisujen yleistyminen.

Digitalisoituminen etenee toki vääjäämättömästi. Makkosen ja kumppaneiden mukaan pian tiedekirjallisuus julkaistaan ensisijaisesti sähköisenä ja vain tarpeen vaatiessa paperisena. Silti he uskovat kirjan aseman oppimisen välineenä jopa vahvistuvan: "kirjan vahvuus on sen hitaudessa." Kirjoittajat painottavat tieteellisen käännöskirjallisuuden merkitystä digitaalisenkin julkaisemisen aikana. Kotimaisilla kielillä julkaistu tiede on ajattelun välineenä tärkeä. Äidinkieli on olennainen osa ajattelun kehittymistä.

Erkki Karvonen käsittelee omassa artikkelissaan tiedettä todellisuuden tuottajana kysymällä, kenen etujen mukaisen todellisuuden rakentamiseen tieteen tulisi osallistua. Artikkelissa käsitellään jossain määrin samoja asioita kuin Karvosen ja kumppaneiden Julkaise tai tuhoudu! -kirjassa. Karvonen tähdentää, että tutkijoiden on entistäkin tärkeämpää olla hyvin valveutuneita eettisestä vastuustaan. Ainakin tänä päivänä ovat vastakkain yksityiset voitot ja maapallon kestokyky.

\section{TUTKIMUS, TUOTTEET JA TULOT}

Tieteen kentällä ja tieteen tehtävien määrittelyssä käydään koko ajan kamppailua maailman merkityksellistämisen tavoista ja kielellisestä hallinnasta. $\mathrm{Ne}$, jotka onnistuvat tekemään omasta diskurssistaan arkijärkeä ja saamaan muut ajattelemaan omien tarkoitusperiensä mukaisilla käsitteillä, voittaa valtapelissä. Kamppailua käydään kaikilla elämän alueilla, yhtä hyvin yliopistomaailmassa ja talouspolitiikassa kuin kulttuurikeskustelussa. Yhteiskuntatieteiden yksi tärkeä tehtävä onkin osoittaa "järkevien" maailman- selitysten ja itsestäänselvyyksien suhteellisuus ja intressisidonnaisuus.

Suvi Ronkainen, Asko Suikkanen ja Marika Kunnari jatkavat omassa artikkelissaan tieteen intressisidonnaisuuden analysoimista. Kysymys on tietämisen intressin alueella käytävästä kamppailusta. Kun "tieteen ulkoinen" ohjaa yhä vahvemmin tieteelliselle tutkimukselle asetettuja tavoitteita, tutkimusongelmat muuntuvat sen mukaisesti.

Yliopistot suuntaavat tutkimustaan kysymyksiin, joihin vastaamalla voi odottaa tuotteita ja tuloja. Se tarkoittaa myös joidenkin toisten tutkimusongelmien syrjäytymistä vähemmän relevantteina, ellei peräti epäkiinnostavina. Tätä kautta rahoitus hyvin vahvasti ohjaa tieteellistä keskustelua. Tutkimuksen olisi oltava hyvin perillä episteemisistä intresseistään: ”Tutkimuksen yhteiskunnallisena tehtävänä on nähdä välittömän hyödyn ohitse ja analysoida myös sitä, miten tietämisen ja tietämättömyyden intressit ohjaavat tiedon tuotannon rakenteita ja mitä näistä seuraa.”

\section{MIELIKUVASTOT OHJAAVAT}

Marja Alastalo, Risto Kunelius ja Reetta Muhonen käsittelevät tutkimuksen vaikuttavuuden mielikuvastoja. Mielikuvastot kuvaavat joko saavutettavissa olevia todellisuuksia tai määrittävät tulevaisuuksia, joiden saavuttamisen välttämättömyyteen valtiot uskovat. Mielikuvastoina "innovaatiotieteellä", "huipputieteellä", "evidenssitieteellä" ja "professio- 
tieteellä" sekä "julkisella tieteellä" on kullakin omat mittarinsa, tuotosten institutionaaliset muotonsa ja käsityksensä vaikuttavuuden kohteesta.

Vaikuttavuuden mielikuvastot määrittyvät kulloistenkin ”pääasiakkaiden" kautta. Kirjoittajat analysoivat esimerkinomaisesti kahta raporttia tutkien, miten niissä hyödynnetään tai "mobilisoidaan” näitä mielikuvastoja. Tieteen kuvastoa tuntuvat hallitsevan tietyt jäsennykset, jotka kytkeytyvät laajempiin yhteiskuntakuvastoihin: "Näissä kuvastoissa valtio kampailee maineestaan maailmalla (huipputiede), pyrkii reagoimaan ja sopeutumaan muuttuvan globaalin ympäristön haasteisiin uskottavin päätöksin (evidenssitiede) ja odottaa tutkimukselta vetoapua kansantaloudelle (innovaatiotiede)." (s. 143.)

Tutkijat pohtivat kiinnostavasti yhteiskuntatieteiden kehityksen ja vaikuttavuusvaatimusten yhteensopivuutta. Samaan aikaan vaikuttavuuden vaatimusten ja hallinnollisen mittaamisen lisääntymisen kanssa yhteiskuntatutkimus on teoreettisesti edennyt suuntaa, johon kovin yksioikoinen mittaaminen ja vaikuttavuuden todistelu ei sovi. Näitä pohdintoja olisi syytä syventää. Asia on kiinnostava ja yhteiskuntatieteen itseymmärryksen kannalta tärkeä.

Alastalo ja kumppanit aiheellisesti peräävät totunnaisten mielikuvastojen oheen laaja-alaisempaa näkökulmaa tieteen vaikuttavuuteen ja tieteen tehtävien artikulointiin. Mikä on esimerkiksi kansalaisyhteiskunnan, yhteiskunnallisten liikkeiden ja yhteiskuntatieteiden oman intressin asema tulevaisuuden vaikuttavuusdiskursseissa? Miten valtion ja markkinoiden ohella ääneen pääsevät yhteiskuntatieteiden muut "strategiset kumppanit"? Merkitseekö esimerkiksi mahdollisten yhteiskunnallisten liikkeiden äänen voimistuminen markkinoiden tai valtion äänen suhteellisen äänivallan pienenemistä?

\section{KUINKA ARVIOIDA \\ VAIKUTTAVUUTTA}

Tieteellisten julkaisujen luokittamisesta laadun mukaan kirjoittavat julkaisufoorumi-hankkeen toteuttajat Otto Auranen ja Janne Pölönen. He kuvaavat julkaisufoorumin taustoja, toteutusta ja erityisesti kotimaisen julkaisemisen asemaa luokituksessa. Artikkelissa on mielenkiintoisia tilastotietoja julkaisujen kielestä (suomi, ruotsi, englanti, muut) eri tieteenaloilla. Vuonna 2011 Suomen yliopistoissa tuotetuista tieteellisistä julkaisuista 77 prosenttia oli englanninkielisiä ja 19 prosenttia suomenkielisiä. Yhteiskuntatieteissä suomenkielisiä oli 38 prosenttia ja humanistisilla aloilla 44 prosenttia.

Tilastot heijastavat eri alojen julkaisukäytäntöjen ja julkaisukielen merkityksen eroja. Erityisen mielenkiintoista on saada havaita, että luonnontieteissä kotimaisten julkaisujen määrä ja osuus alan julkaisuista on pienentynyt vuosien 1994 ja 2011 tarkastelujaksolla. Samoin ihmistieteissä on kotimaisten julkaisujen osuus pienentynyt, mutta määrä selvästi kasvanut. Kasvua selittää ennen kaikkea tutkimushenkilöstön määrän lisääntyminen.

Ainakaan vuoteen 2011 mennessä kotimaisen julkaisemisen volyymi ei ole ollut ihmistieteissä laskusuunnassa. Tosin OKM:n uuden rahoitusmallin vaikutusta ei voi vielä arvioida. Lähivuosina siitä jo saa tietoa. Olisi ensiarvoisen tärkeää saada vuosittain raportti eri tieteenaloilla tuotettujen julkaisujen kielijakaumasta.

Kirjoittajat pohtivat myös julkaisukielen ja yhteiskunnallisen vaikuttavuuden yhteyttä, ja toteavat, että ihmistieteellisen julkaisutoiminnan tieteellinen ja yhteiskunnallinen vaikuttavuus sekoitetaan helposti keskenään: "Suomenkielisillä tieteellisillä julkaisuilla ei itsestään selvästi ole laajaa vaikutusta tiedeyhteisön ulkopuolella." Kyllä itse kunkin suomenkielisen julkaisutoiminnan puolesta puhuvan on syytä ennakkoluulottomasti pohtia, miten kotimaisilla kielillä laadittujen tieteellisten julkaisujen vaikuttavuus voidaan todentaa. Jos se todentamista tarvitsee. Journaalien lukijakunnan laajuuden arvioiminen lienee helpompi tehtävä, mutta se ei ole koko totuus vaikuttavuudesta.

\section{TUTKIMUSLAITOKSET} JOHTAVAT JULKAISUMÄÄRISSÄ

Elina Late ja Hanna-Mari Puuska tekevät analyysiä yliopistojen ja valtion tutkimuslaitosten tutkimusorientaatioista ja niiden eroista. Ennakko-oletushan on, 
että yliopistot keskittyvät enemmän akateemista yhteisöä palvelevaan perustutkimukseen ja valtion tutkimuslaitokset puolestaan tuottavat soveltavaa tutkimusta päätöksentekijöiden tarpeisiin. Tutkimusrahoituksessa, tutkimushenkilöstön rakenteessa, tutkimuksen luonteessa ja julkaisukäytännöissä on eroja, mutta myös yhtäläisyyksiä.

Vaikka valtiovallan panostukset ovat viime vuosikymmeninä olleet selvästi suuremmat yliopistotutkimukseen kuin valtion tutkimuslaitosten tutkimustoimintaan, valtion tutkimuslaitosten julkaisumäärät ovat kasvaneet suhteellisesti enemmän. Julkaisumäärien ohella artikkelien tieteellistä vaikuttavuutta arvioidaan 1990- ja 2000-luvuilla. Valtion tutkimuslaitosten julkaisujen keskimääräiset viittausmäärät ovat yliopistojulkaisuja suuremmat, mikä on yhdenlainen osoitus tutkimuslaitosten tieteellisestä vaikuttavuudesta.

Tutkimustulosten hyödyntämisestä kirjoittavat Jouni Välijärvi (PISA-arvioinnit) ja Timo Turja (kansanedustajien viittaamat kirjat). PISA-tutkimusten vaikutuksia eri maissa koulutuksesta käytyyn keskusteluun on runsaasti näyttöä. Monissa verraten heikosti menestyneissä maissa (kuten Saksassa, Australiassa, Ruotsissa) on kärsitty jonkinlaisesta PISA-shokista. Kouluuudistuksia perustellaan yhä useammin PISA-tuloksilla.

Suomessa PISA-tulosten vaikutus näkyy Välijärven mukaan siinä, että koulupolitiikassa ei ole tehty suuria muutoksia. Viimeisimmässä PISA-testauksessa suomalaisnuorten heikentynyt menestys lienee ollut yksi syy sille, että opetusministeriö asetti asiantuntijaryhmän etsimään keinoja oppimisympäristöjen uudistamiseksi ja koulumotivaation vahvistamiseksi. Kaikkineen PISA:n vaikutus eri maiden koulutuspolitiikkaan ja kouluuudistuksiin on suuri. Aina eivät vaikutukset suinkaan ole olleet yksiselitteisen myönteisiä. Esimerkiksi kontrolloivaa arviointia on monissa maissa tiukennettu. OECD on tutkimuksineen entistä vahvempi koulutuspoliittinen vaikuttaja.

\section{TIEDE KILPAILEE}

\section{KLASSIKKOTEOSTEN KANSSA}

Eduskunnan kirjaston johtava tietoasiantuntija Timo Turja analysoi artikkelissaan, miten kansanedustajat käyttävät kirjoja parlamentaarisessa politiikassa ja retoriikassa. Aineisto kattaa peräti sata vuotta. Kansanedustajat hakevat kirjoista argumentteja ja retorista tukea omille näkemyksilleen. Eri maiden parlamenteissa suhtaudutaan eri tavoin kirjallisiin siteerauksiin ja katkelmien lainaamiseen kirjoista. Siihen on olemassa tietyt säännöt myös Suomessa. Kirjoista ei haeta vain faktoja. Niiden avulla vedotaan tunteisiin.

Turja listaa kansanedustajien "tärkeimmät kirjat". Niiden joukkoon kuuluvat Raamattu, Seitsemän veljestä ja Tuntematon sotilas. Varsinaiset tieteelliset teokset eivät kärkisijoja valloita. Pekka
Kuusi ja Max Jakobson kuitenkin kuuluvat kansanedustajien lukemistoon. Kun kansanedustaja haluaa puheelleen auktoriteettia, hän viittaa Kekkoseen.

Hyvän tieteen määrittely osoittautuu käytännön kiistoissa ja rajanvedoissa paitsi moniselitteiseksi myös tutkimuksellisesti kiintoisaksi asiaksi. Hyvä tiede on tietenkin laadukasta, järjestelmällistä ja kriittistä, mutta kuten Pia Vuolannon käyttämät esimerkkitapaukset osoittavat, tieteensisäiset rajanvedot avaavat hyvin monimuotoisen keskustelun. Toisessa esimerkkitapauksessa Vuolanto kuvaa Pekka Himasen ja Manuel Castellsin Kestävän kasvun malli -raportin saamaa kritiikkiä rajanvedon näkökulmasta. Tieteen kannalta rajanvetokiistat ovat itse asiassa hyödyllisiä, vaikka kulloisenkin kohteen kannalta ikäviä.

\section{JYRÄÄKÖ MÄÄRÄ LAADUN?}

Arto Mustajoki kysyy artikkelissaan, jättääkö arvioinnin ja mittaamisen hurmos tilaa luovalle ajattelulle, ja onko tulosten alituiselle mittaamisella vaihtoehtoja. Hän käy läpi erilaisia prosesseja, joissa julkaisut, tutkijat ja tieteenalat tulevat arvioiduiksi. Akateeminen elämä on kauttaaltaan arviointien kyllästämää.

Mustajoki erittelee mittaamisen haittavaikutuksia ja keinoja niiden minimoimiseen. Yhtenä haittavaikutuksena on "liika julkaiseminen" ja julkaisujen pirstominen lukumäärän kasvattamiseksi. Niin ikään arvioinnit ja niiden pohjana olevat mittarit 
kohtelevat tieteenaloja epäsuhtaisesti ja epäoikeudenmukaisesti. Sen korjaamiseksi olisi syytä ottaa käyttöön alavakiointi, jolloin tieteenalojen "tuottavuutta" tai julkaisujen laatua ei verrattaisi keskenään.

Samoin painotukset tieteenalojen sisällä tulisi ottaa huomioon. Käytettävien mittarien suosimat tutkimusalat nimittäin saattavat houkuttaa tutkijoita ja tulospisteitä (ja niiden tuomaa rahoitusta) tavalla, joka on haitallista huonosti mittauksissa menestyvien alojen tutkimukselle sen yhteiskunnallisesta merkityksestä huolimatta.

Mekaaninen mittareiden käyttö voi johtaa jopa tutkimuksen umpioitumisen ja yhteiskunnallisen relevanssin vähenemi- seen. Myös tieteen avoimuus voi kärsiä, jos tutkijat oman suhteellisen kilpailuetunsa vuoksi pidättäytyvät oman tutkimusdatan jakamisesta yleiseen käyttöön. Julkaisujen avoimen saatavuuden osalta tutkijat ovat kustantajien tiukassa kontrollissa.

Jorma Sipilä varoittelee englanninkielisen julkaisemisen korostamisen epätoivottavista sivuvaikutuksista: "se viettelee luovuttamaan vallan tieteen sisällöstä kustantajille, joita kiinnostavat vain maailmanlaajuiset markkinat.” Tämä vaikuttaa siihen, mitä tutkijoiden kannattaa tutkia saadakseen aikaan merkittäviksi noteerattuja julkaisuja. Suomalaisen yhteiskunnan tutkiminen ei ole tässä laskelmassa kaikkein järkevintä.
Tieteen kansallinen tehtävä on moniaineksinen ja runsaasti kiinnostavaa tietoa ja pohdintoja sisältävä teos. Kirjan artikkelit ovat itsenäisiä kokonaisuuksia, joista voi poimia luettavansa kiinnostuksen mukaan. Tiedepolitiikasta ja yliopiston tilasta kiinnostuneet löytävät kirjasta ravintoa ajatteluun. Kansalaisyhteiskunnan suhde tieteeseen ja julkisesti rahoitettuun tutkimukseen on aihe, josta soisi kirjoitettavan enemmänkin. Yliopistoissa teos saa runsaasti lukijoita, mutta helppolukuisena se voi tavoittaa muutakin valistunutta yleisöä.

Heikki Silvennoinen 